\title{
THE ROLE OF HISTORICAL SCIENCES ON THE DEVELOPMENT OF URBAN PUBLIC TRANSPORTATION IN 21st CENTURY INDONESIA
}

\author{
${ }^{1}$ Muhammad Luthfi Lazuardi, ${ }^{2}$ Moses Glorino Rumambo Pandin \\ ${ }^{12}$ Faculty of Humanities, Airlangga University \\ muhammad.luthfi.lazuardi-2020@ fib.unair.ac.id; moses.glorino@ fib.unair.ac.id
}

\begin{abstract}
Public transportation is one of the most critical needs for a city, including in Indonesia. The fast and dynamic movement of society makes public transportation expected to accommodate the needs of city residents to move more quickly and efficiently. Available public transport can also reduce congestion because many city residents are switching from their private vehicles. Many cities in Indonesia are competing to develop their public transportation to modernize the life of the town. Problems will arise if the city government does not learn from history in planning the development of public transport in the city. This study aims to examine the role of historical science in the development of urban public transportation in Indonesia. The method used in this research is descriptive-qualitative through literature review by analyzing data and information according to the topic of the research topic. The data and information are sourced from 20 journal articles and five credible online portal sites with published years between 2019-2021. The result of this study is the role of historical science in the development of urban public transportation in Indonesia as a reference for city governments to reorganize their transportation systems in the future. This research has research limitations on the development of urban public transport in Indonesia in the 21 st century. The researcher recommends further research on the role and benefits of historical science in improving urban public transportation in Indonesia to complement some lacking things from this research. At the same time was adding to the scientific treasures for many people, significant position holders in city government to be more intense in using historical knowledge as an essential study to encourage a better civilization of a city by improving the public transportation system.
\end{abstract}

Keywords: History, Urban, Public Transportation 


\section{INTRODUCTION}

Public transportation has become one of the vital elements that not serve as transportation for humans to move from place to place but also has other significant contributions. Public transportation plays a crucial role in supporting the economic growth and development of a region, including urban areas. Therefore, economic development will be successful if it is supported by the development of a sound transportation system following the needs of society and the times. Public transportation is also a representation of the life of a city, which means that the more modern the city's transportation system is, the more advanced the pace of city life is. Therefore, it makes cities in Indonesia compete to develop their public transportation.

The decision of these cities to accelerate the development and renewal of their public transportation network is the impact of the rapidly increasing population. The need for transportation that can accommodate the movement of the city's population also increases. City government officials certainly do not want their area to be plagued by traffic jams and air pollution caused by private vehicles of its citizens roaming the streets. As a result, the concept of sustainable transportation is a big step to change the city's order for the better and more advanced. Sustainable transportation is an important thing to be developed in cities, especially cities that bear the title of metropolitan Indonesia, such as Jakarta, Jogjakarta, Bandung, and Surabaya. In addition to making transportation more efficient and effective, transportation with a sustainable concept will make the urban environment and surrounding areas more comfortable (1). The community will be significantly facilitated by the mobility of this public transportation anywhere, anytime, and anywhere. A city will not be able to live without public transportation. However, not all people can meet their own needs. There must be those who depend on public transportation to meet their mobility needs because they do not have or do not have private vehicles (2).

Many things need to be considered by the city government to realize the development plan. So far, what has crossed the minds of those who hold positions is the importance of establishing intense communication with economists to calculate the costs incurred and the profit and loss that will be obtained. Legal experts in preparing legal umbrellas for ongoing projects. Transportation experts in negotiating on analyzing the public transportation plan in urban spatial planning.

Mayors and heads of agencies associated with the project need to understand that the science of history can be a link between the problems faced today in the $21 \mathrm{st}$ 
century and similar situations in the past. Therefore, this article aims to analyze the role of historical science in the development of urban public transportation in Indonesia. Thus, it becomes the basis for the city government to connect events experienced in the 21 st century with past events to run the target.

\section{METHODS}

The method used by the researcher is a qualitative approach that refers to the postpositivism philosophy. The method based on postpositivism is used in scientific research with objects in nature, not in experiments, and the researcher's position as a critical instrument in research. The results of research using qualitative methods emphasize more on meaning than generalization (26). The data used in this study were obtained from 3 different types of sources, namely electronic books, journal articles, and credible websites. Researchers used 28 sources consisting of 3 electronic books, 20 journal articles, and 5 credible and trusted websites. Details of the 20 journal articles used are 12 editions of 2019 and 8 of 2020 publications. Researchers also use trusted websites with details of 4 websites in 2020 and 1 website in 2021 .

The data obtained from the source is data following the topic of discussion in this study. The information obtained utilizing a literature review is a basic review used by the author to conduct further research following in-depth discussion topics (27). This type of technique is used by researchers in conducting preliminary studies to find the central problem to be discussed. At the same time, the type of descriptive analysis technique used is statistics to analyze data by describing the data obtained and collected as is without intending to write conclusions that apply in general or known as generalizations.

At this stage, the researcher sorts and processes the data that has been obtained. Furthermore, the information is shown in the form of paragraph text and tables. Then the data is analyzed so that conclusions can be drawn (28). The details of the analysis process carried out by researchers are as follows: 1. Researchers do sorting and processing data according to the discussion. 2. Researchers present data in text form, and a summary table of results contain in the appendix. 3. Draw conclusions based on the data obtained by analyzing the data.

\section{RESULTS}

This study obtained 20 journal articles with published years between 2019-2021 plus 5 credible official website portals. Researchers downloaded journal articles from various sites ranging from Google Scholar to journal sites affiliated with several 
universities in Indonesia. The majority of journal articles used are 2019 outputs with 12 pieces, while 2020 journal articles output 8 pieces. Details of the 5 official website portals used are 4 websites from 2020 and 1 website from 2021. The total number of research references used by researchers is 25 pieces.

In this study, researchers found the results obtained from the data set that had been collected. In the first part, the researcher presents the definition of history based on the thought of the British historian Sir Charles Firth. Still, in the first part, the researcher also explains the role and benefits of historical science for humans to be wise. Finally, the researcher presents urban public transportation projects in Indonesia built in the 21 st century in the second part. Researchers included information from the Jakarta MRT, Palembang LRT, Suroboyo Bus, Trans Jogja, and Batik Solo Trans projects. The four transportation projects have become public transportation that is relied on by the people of their respective cities to support daily mobility.

The researcher presents public transportation projects that are considered not going well in the third part, and some have even failed to realize. For example, researchers included information about the Mamminasata BRT, Trans Semarang BRT, and Jakarta Monorail transportation projects. However, the three projects failed to solve the urban community's need for public transportation and added to the burden on the city government.

In the fourth part, the researcher presents the role that historical science has played in developing urban transportation in Indonesia. City governments can combine the knowledge gained from historical studies with studies of other disciplines in designing the concept of improving their urban transportation system. The merger result is expected to emerge policies for developing and managing better and more organized transportation.

\section{DISCUSSION}

\section{A. History and Historical Sciences}

History is closely related to time and events. Historians make periodizations to overcome the problem of the importance of time in historical reconstruction. And, historians have their definition in interpreting history. According to the British historian Sir Charles Firth, history records human life, its ongoing changes, records ideas, and documents the material conditions that aid or hinder its development (3).

The Western world regards Herodotus as the world's first historian. Herodotus is an ancient Greek historian who lived around the 5th century AD. Together with another 
Greek historian, Thucydides, he formed the basis of the modern study of human history. Science ancient history has had a significant influence in helping to understand the variants of the nature of history that have continued to develop into this century. The study of modern history is also increasingly widespread, including researching specific areas and analyzing particular topics or thematic elements in historical investigation. History has an urgency that makes it a part of the primary and secondary education curriculum. History is also an essential science in scientific research activities at the university level. History is a social science that discusses three dimensions of time, past, present, and future. The dimensions of time are interrelated with each other and cannot be separated (4).

History is a science that is open to knowing life in the past (5). History can make a person wise because the experience of both failure and success in the past can provide a reference for someone in the present to create intelligent rules. Therefore, humans should study every consequence that results from the things they do. History is a branch of science that systematically examines the overall development, the process of changing people's lives that occurred in the past, intending to pass down virtue values to generations who study them (6).

\section{B. Urban Public Transport Projects in 21st Century Indonesia 1. MRT Jakarta}

Mass Rapid Transit or MRT is an electric rail-based mass transportation system that provides a practical, comfortable, and fast feeling. The MRT Jakarta officially operated on March 24, 2019. The Mass Rapid Transit (MRT) serves routes that stretch from Lebak Bulus station to Bundaran HI station. . MRT Jakarta is presented as a mode of transportation that provides practical, safe, and affordable public service access. MRT is obliged to provide the best service to MRT users (7).

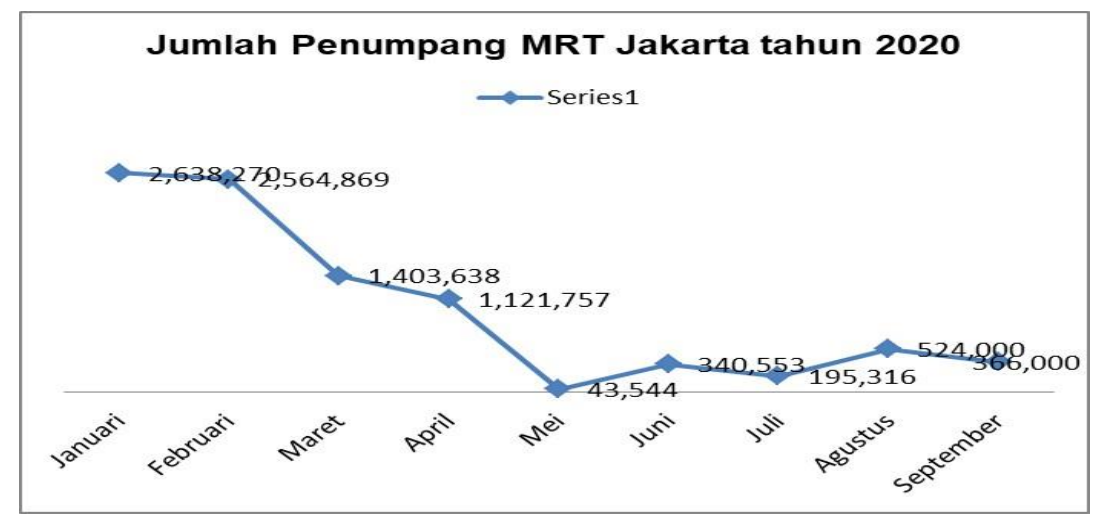

Figure 1. Number of MRT Jakarta passengers 


\section{LRT Palembang}

The South Sumatra Light Rail Transit (LRT) mode of transportation is public transportation such as the Jakarta MRT, which is expected to solve transportation problems in Palembang. The South Sumatra LRT transport, operating in the urban area of Palembang City, crosses 13 stations and is connected to the previous operating Trans Musi and DAMRI bus services (8). The South Sumatra LRT built intending to be an alternative mode of public transportation in Palembang, the capital of South Sumatra Province. This train-based transportation began operating in 2018 to coincide with the XVIII Asian Games sports party, which was also held in Jakarta. This project has a route coverage of 23.40 kilometers starting from Sultan Mahmud Badaruddin International Airport to the Jakabaring Sports Complex and crossing the Musi River as one of the longest rivers in Indonesia with a span of 435 meters.

\section{Suroboyo Bus}

Inaugurated in April 2018, Suroboyo Bus is the second mass transportation system to implement a payment system using plastic waste (9). Before the Surabaya City Government initiated the Suroboyo Bus, Beijing had already implemented plastic waste payments for their subway transportation. Suroboyo bus does not accept payment using money in the form of paper or coins. Bus passengers have to pay using plastic waste as a substitute for cash. The Suroboyo Bus facility was inaugurated by the Mayor of Surabaya Tri Rismaharini on April 7 2018. The people of Surabaya city well-received this innovation because the presence of this bus fleet greatly facilitates the mobility of people from various groups, including the lower middle class.

\section{Trans Jogja}

Starting in 2004, Yogyakarta has a public transportation mode system managed by the city government, Trans Jogja. The system used by Trans Jogja is the Bus Rapid Transit (BRT) system (10). The system used by Trans Jogja is similar to TransJakarta, namely using buses by implementing a closed system, which means that passengers who want to board cannot enter the bus without passing through an inspection tool. As a way to revive transportation in Sleman Regency, the DIY Transportation Service launched the addition of three Trans Jogja routes, namely the Godean, Ngaglik, and Ngemplak routes, by implementing a program called Buy The Service. With this addition, the target of the Trans Jogja route coverage of 25 sub-districts has been successfully realized. Nevertheless, having a new route and fleet is a breakthrough from the collaboration with PT AMI with the DIY government which is a 
collaboration between each other by always wanting to develop and advance public transportation in the city of Jogja (11).

\section{Batik Solo Trans}

Batik Solo Trans was inaugurated directly by Mayor Joko Widodo on September 1, 2010. This transportation serves the Adi Soemarmo International Airport route to Palur Terminal as corridor 1 at the beginning of its operation. This transportation service is expected to overcome and reduce congestion in Solo. Batik Solo Trans mode allows people to move from one place to another (12). Starting on July 4, 2020, Batik Solo Trans uses a travel service purchase system by Teman Bus, which the Directorate General of Land Transportation launched. It is a plan that all corridors will use this system. However, only corridor 3 and corridor 4 are ready to implement it because the fleet is still feasible.

Meanwhile, Corridor 1 and Corridor 2 have not yet implemented it because they are waiting to make a new fleet. After the operation of the Teman Bus service purchase system, the changed several BST corridor routes to avoid overlapping and be more efficient. In addition, the Teman Bus BST service requires passengers to be independent in payment with a non-cash system because no flight attendants/stewardesses are serving each fleet. The Solo City Government has taken the proper steps by encouraging its citizens to use public transportation modes.

\section{Less Successful Public Transportation Projects In Indonesia}

Researchers took 3 case studies from urban public transportation projects in Indonesia that did not run according to the target, causing new problems for the city government as the project owner. The case studies selected were BRT Mamminasata (Makassar), BRT Trans Semarang (Semarang), and Monorail Jakarta (Jakarta).

\section{BRT Mamminasata}

Trans Mamminasata was a bus rapid transit (BRT) mass transit service in Makassar City in March 2014. The first corridor to open is the GTC Mall - Panakkukang Mall route. Initially, the project, which cost Rp. 36.8 billion, was expected to support the activities of Makassar residents, especially regarding the safety and comfort of passengers. This expectation did not go well because, in its development, the transportation service on the Mamnisata BRT had not been running effectively. Integrating the transportation system through the BRT project has prepared several infrastructure facilities, such as the opening of bus stop corridors that already have Bus Line lanes but are not optimal because they do not have their Busway lanes. They 
still pass through public roads and other vehicles even though BRT can maximize and effectively use Busway lanes. (13). Mass transportation services using buses (Bus Rapid Transit) are still low because bus stops are still difficult to reach even though they are very affordable and provide more convenience than other mass transportation. Other problems also arise when hundreds of bus rapid transit (BRT) stops in Makassar appear abandoned and increasingly neglected. The problem of transportation in the Mamminasata Area is not only on external factors, but problems can also occur in the internal government in formulating policies that are not balanced with their implementation, to carry out the programs that have been determined (14).

\section{BRT Trans Semarang}

Trans Semarang is an integrated highway bus transportation system in Central Java that operates in the city and (partly) of Semarang Regency. This service reduces congestion in Semarang and accommodates people to the city center and tourist destinations in Semarang. The entire operation began on September 18, 2009, with establishing a consortium of PT Trans Semarang (from Perum DAMRI, PO Minas, and PO Ratakencana) and a bus asset rental system between the Semarang City government and the consortium. Trans Semarang buses or some community members call BRT Trans Semarang, in 2017, have 6 (six) corridors.

\begin{tabular}{|l|l|l|}
\hline No & Koridor & Tahun Operasi \\
\hline 1. & Mangkang-Penggaron & 2010 \\
\hline 2. & Terboyo-Sisemut & 2012 \\
\hline 3. & Cangkiran-Bandara Ahmad Yani & 2013 \\
\hline 4. & $\begin{array}{l}\text { Pelabuhan Tanjung Mas-Taman } \\
\text { Diponegoro }\end{array}$ & 2014 \\
\hline 5. & Meteseh-PRPP & 2017 \\
\hline 6. & UNDIP-UNNES & 2017 \\
\hline 7. & Genuk-Balaikota & 2017 \\
\hline
\end{tabular}

Tabel 1. Trans Semarang Corridors 2018

Now in 2020, it has 8 (eight) main halls and 1 (one) particular corridor, and 3 (three) feeder corridors (15). However, the implementation of BRT in Semarang City is to add a new public transportation system and organize and change the management system from conventional public transportation to be more organized and orderly (16). The expectation of the Semarang City government to make Trans Semarang a 
suitable mode of transportation seems to be hampered by several problems. The city government is faced with many complaints related to the performance of the Trans Semarang fleet, such as the fleet not docked at the bus stop/shelter, the lack of service for bus drivers, the condition of the bus fleet that is not prime, arrival delays, and so on.

\section{Jakarta Monorail}

Entering the early 21st century, the DKI Jakarta Government has the ambition to build a modern public transportation system to develop transportation networks in the capital, one of which is by creating a monorail. The construction of poles for the construction of the Jakarta monorail project began in 2004, which was carried out by a consortium of PT Jakarta Monorail and Omnico Singapore (17). 5th President Megawati Soekarnoputri inaugurated its construction in June 2004. PT Adhi Karya initially held the project during the era of the Governor of DKI Sutiyoso. Previously, PT Jakarta Monorail had conducted a foundation load test on the Asia-Africa monorail line. However, this project also stopped the work because the contractor had difficulty getting funds. PT Jakarta Monorail admitted that it was difficult to obtain funds because the government did not participate in the project. The monorail project is estimated to cost an investment of US\$ 670 million, with around US\$ 470 million of the project funds being borrowed from abroad. The failure of the project began to appear after several years of construction. When the monorail pole was plugged in, DKI Governor Fauzi Bowo (who replaced Sutiyoso) stopped the structure due to financial problems (18).

\section{The Role of History in the Development of Transportation}

Transportation projects considered less successful in achieving these targets can already be history because they occurred in the past. Herein lies the importance of the role of historical science for the development of public transportation. History makes people wise. Experiences of failure and success provide references for today's people to make wise policies. The losses or obstacles experienced by public transportation projects, as previously mentioned, need to be studied in depth by the incumbents, they can develop a better transportation system so that they do not repeat the same development mistakes. After examining more deeply the shortcomings that occurred in the past,

The city government can use the data from this history to fix some aspects that were not implemented before. First, the development of public transportation needs to 
create effectiveness and efficiency. Following the principles of Good Governance, namely energy and efficiency in serving the community, the government should create public facilities, especially public transportation facilities that make it easier for people to move in a country, to measure whether a country is seen as a developing country in the future (19). Second, an excellent urban public transportation system must have connections with other sectors of life, for example, the tourism sector. Therefore, it is necessary to improve integrated public transport services, to harmonize the functions and objectives of tourism to strengthen the economy and the quality of human resources contained in the tourist area (20). Third, an excellent urban public transportation system must be integrated to make it easier for users, as an example applied by the DKI Jakarta Government. The DKI Jakarta Provincial Government targets all public transportation in Jakarta to be integrated with the Jak Lingko system by 2020 (21). Fourth, the urban public transportation system should install cheap service fees or travel tickets. Transportation costs reflect people's expenditures to pay for transportation costs (22). Fifth, an excellent public transportation system should have technology that supports its services. Information technology-based public services need to implement to reduce the risk of discrimination in providing services, uncertainty regarding the time or cost of services, and of course, reducing illegal fees that often occur (23). Sixth, adequate infrastructure is also a key to the progress of urban public transportation. An example is a route. Public transport routes are endeavored as close as possible to reach areas of high population density, generally being areas with high potential demand (24). Lastly, should not forget accessibility to develop quality transportation-for example, the case study of Trans Padang transportation for accessibility matters. The accessibility referred to in this case is the ease of movement of passengers to the bus stop location (25).

\section{CONCLUSION}

Public transportation is one of the things that cities in Indonesia need to have to support the daily activities of their people. The presence of transportation will also impact other sectors in the city, for example, the economy. No wonder many cities are competing to develop their transportation systems to suit their needs. The role of historical science emerges to provide a reference for today's humans to make wise policies in the future so as not to repeat the same thing in the past. In terms of urban public transportation development in Indonesia, historical science has a role as a 
benchmark for the city-level government to design better and planned public transportation policies not to repeat some of the failures of these urban transportation projects in the past. City governments can also combine the knowledge gained after studying history with other disciplines in managing the development and improvement of their public transportation. The limitation of this research is the role of historical science in the development of public transportation in urban areas, which are only in Indonesia in the 21st century. The researcher recommends further research on the role and benefits of historical science in improving urban public transportation in Indonesia to complement some lacking things from this research. At the same time, adding to the scientific treasures for many people, significant position holders in city government to be more intense in using historical knowledge as an essential study to encourage a better civilization of a city through the improvement of the public transportation system.

\section{BIBLIOGRAPHY}

1. Nugraha AA, Purnomo EP, Kasiwi AN. Kesiapan Kota Yogyakarta dalam Pembangunan Transportasi yang Berkelanjutan. Din J Ilm Ilmu Adm Negara. 2020;07(01):148-58.

2. Haqie ZA, Nadiah RE, Ariyani OP. Inovasi Pelayanan Publik Suroboyo Bis di Kota Surabaya. J Public Sect Innov. 2020;05(01):23-30.

3. Anwar IC. Apa Saja Pengertian dan Definisi Ilmu Sejarah Menurut Para Ahli? [Internet]. Tirto. 2021 [cited 2021 May 28]. Available from: https://tirto.id/apa-sajapengertian-dan-definisi-ilmu-sejarah-menurut-para-ahli-f8Vl

4. Setyaningsih W. Mengulik Sejarah Melalui Pemanfaatan Perpustakaan. PUSTABIBLIA J Libr Inf Sci. 2019;03(02):205-22.

5. Kompas. Manfaat Sejarah: Intrinsik dan Ekstrinsik [Internet]. Kompas. 2020 [cited 2021 May 28]. Available from: https://www.kompas.com/skola/read/2020/07/20/162204469/manfaat-sejarahintrinsik-dan-ekstrinsik

6. .Batubara UN, Aman. Perkembangan Pembelajaran Sejarah Pasca Kemerdekaan-Reformasi. J Pendidik Sej. 2019;08(01):14-34.

7. .Yuniarti A, Aditya T. Service Quality Terhadap Kepuasan Masyarakat Mass Rapid Transit (MRT) DKI Jakarta di Stasiun Lebak Bulus pada Masa Pandemik Covid-19. J Ilm Ilmu Adm. 2020;10(02):55-69.

8. Widiyanti D. Pengembangan Park and Ride untuk Meningkatkan Pelayanan Angkutan LRT Kota Palembang. J Penelit Transp Darat. 2019;21(02):103-16. 
9. M RNL. Naik Bus Tanpa Uang, Penumpang Suroboyo Bus Membayar Tiket dengan Sampah Plastik [Internet]. Merdeka. 2020 [cited 2021 May 28]. Available from: https://www.merdeka.com/jatim/naik-bus-tanpa-uang-penumpang-suroboyobus-membayar-tiket-dengan-sampah-plastik.htm.

10. Valentine V, Devi MK, Pramana AYE. Jangkauan Layanan Trans Jogja Terhadap Sebaran Aktivitas di Kawasan Perkotaan Yogyakarta. J Transp. 2020;20(03):171-80.

11. Hayati KZ Al, Al-Hamdi R. Transportasi Publik dan Media Sosial: Persepsi Netizen Terhadap Pelayanan Bus Trans Jogja 2016-2018. J Ilmu Pemerintah Widya Praja. 2019;45(02):127-39.

12. Nugroho RA, Santoso EB, Susetyo C. Konsep Manajemen Trans Batik Solo sebagai Pendukung Sektor Pariwisata di Kota Surakarta. J Manaj Aset Infrastruktur dan Fasilitas. 2019;03(01):49-58.

13. Rachmat AW, Prianto AL, Hamrun, Nurmaeta S. Pengembangan Transportasi Publik Berbasis Smart Mobility Di Kota Makassar. FisiPublik J Ilmu Sos dan Polit. 2019;04(01):12-20.

14. Bau QD, Muhajir R, Surya B. Kinerja Pelayanan Bus Trans Mamminasata di Koridor 3 Kawasan Mamminasata. J HPJI. 2019;05(02):75-840.

15. Yulizar RHA, Narendra A. Analisis Hubungan Jumlah Penumpang dan Waktu Pelayanan BRT Trans Semarang di Halte Simpang Lima dan Halte Kampung Pelangi. J Teknol Transp dan Logistik. 2020;01(02):59-66.

16. Priatama RF, Subowo A. Evaluasi Pelaksanaan Kebijakan Bus Rapid Transit (BRT) Trans Semarang Rute Koridor VI Jurusan “Undip-Unnes.” J Public Policy Manag Rev. 2020;09(01):1-15.

17. Wijaya LD. No TitleLika-liku Mangkraknya Proyek Monorel Jakarta, Dihidupkan Jokowi lalu Dihentikan Ahok [Internet]. Metro tempo. 2020 [cited 2021 May 28]. Available from: https://metro.tempo.co/read/1398772/lika-likumangkraknya-proyek-monorel-jakarta-dihidupkan-jokowi-lalu-dihentikan-ahok

18. Voi. Nasib 'Fosil' Tiang Monorel Jakarta yang Mangkrak Berada di Ujung Tanduk [Internet]. Voi. 2020 [cited 2021 May 28]. Available from: https://voi.id/berita/17718/nasib-fosil-tiang-monorel-jakarta-yang-mangkrak-beradadi-ujung-tanduk

19. Wijayanto H. Peranan Penggunaan Transportasi Publik di Perkotaan (Studi Kasus Penggunaan Kereta Commuterline Indonesia Rute Jakarta-Bekasi). Kybernan J Stud Kepemerintahan. 2019;02(02):1-8. 
20. Utami AL. Potensi Transportasi Umum dalam Mendukung Pengembangan Pariwisata Kota Palangkaraya. J Transp. 2020;20(03):201-12.

21. Alexandri MB, Novel N. Pengelolaan Angkutan Kota di Indonesia. Responsive. 2019;02(04):182-9.

22. Suryani F, Natadipura RK, Tunafiah H. Optimalisasi Rute Perjalanan Sarana Angkutan Umum Terpadu Bogor-Jakarta. IKRA-ITH Teknol. 2019;03(02):63-75.

23. . Nasikhah MA. Inovasi Pelayanan Transportasi Publik Berbasis Teknologi Informasi. JISOP J Inov Ilmu Sos dan Polit. 2019;01(01):26-37.

24. Nurdiani D, Astuti W, Rini EF. Kesesuaian Sistem Transportasi Umum di Kota Surakarta Terhadap Konsep Transportation for Livable City. Desa-Kota. 2019;01(01):71-83.

25. Putri RTA, Mariya S. Efektivitas Bus Trans Padang sebagai Moda Transportasi Publik di Kota Padang. J Buana. 2020;04(03):570-86.

26. Sugiyono. Metode Penelitian Pendidikan (Pendekatan Kuantitatif, Kualitatif, dan R\&D). Bandung: Penerbit Alfabeta. 2015

27. Zed M. Metode Penelitian Kepustakaan. Jakarta: Yayasan Obor Indonesia. 2008.

28. Sidiq U, Choiri M. Metode Penelitian Kualitatif di Bidang Pendidikan. Ponorogo: CV Nata Karya. 2019.

\section{ATTACHMENT}

Table 1. Summary of Results from Journal Articles

\begin{tabular}{|c|c|c|c|}
\hline Author & Method & $\begin{array}{l}\text { Title and Year of } \\
\text { Publication }\end{array}$ & Result \\
\hline $\begin{array}{lr}\text { Andika } & \text { Alam } \\
\text { Nugraha } & \\
\text { Eko } & \text { Priyo } \\
\text { Purnomo } & \\
\text { Aulia Nur Kasiwi }\end{array}$ & $\begin{array}{l}\text { qualitative by } \\
\text { using analysis } \\
\text { study literature or } \\
\text { literature review. }\end{array}$ & $\begin{array}{l}\text { KESIAPAN KOTA } \\
\text { YOGYAKARTA } \\
\text { DALAM } \\
\text { PEMBANGUNAN } \\
\text { TRANSPORTASI } \\
\text { YANG } \\
\text { BERKELANJUTAN } \\
(2020)\end{array}$ & $\begin{array}{l}\text { More efficient and } \\
\text { effective } \\
\text { sustainable } \\
\text { transportation } \\
\text { concept }\end{array}$ \\
\hline $\begin{array}{lr}\text { Zulfa } & \text { Auliana } \\
\text { Haqie } & \\
\text { Rifda Eka Nadiah } \\
\text { Oktavira } \quad \text { Puteri } \\
\text { Ariyani }\end{array}$ & $\begin{array}{ll}\text { literature } & \text { study } \\
\text { research } & \end{array}$ & $\begin{array}{l}\text { INOVASI } \\
\text { PELAYANAN } \\
\text { PUBLIK } \\
\text { SUROBOYO BIS DI } \\
\text { KOTA SURABAYA } \\
(2020)\end{array}$ & $\begin{array}{l}\text { Public } \\
\text { transportation is } \\
\text { very influential for } \\
\text { the life of a city } \\
\text { and its residents } \\
\text { for mobility needs }\end{array}$ \\
\hline
\end{tabular}




\begin{tabular}{|c|c|c|c|}
\hline $\begin{array}{l}\text { Wahyu } \\
\text { Setyaningsih }\end{array}$ & Literature review & $\begin{array}{l}\text { Mengulik Sejarah } \\
\text { Melalui Pemanfaatan } \\
\text { Perpustakaan (2019) }\end{array}$ & $\begin{array}{l}\text { History is a social } \\
\text { science that deals } \\
\text { with the three } \\
\text { dimensions of } \\
\text { time, past, present, } \\
\text { and future }\end{array}$ \\
\hline $\begin{array}{l}\text { Ulfah Nury } \\
\text { Batubara, Aman }\end{array}$ & $\begin{array}{l}\text { descriptive } \\
\text { research }\end{array}$ & $\begin{array}{l}\text { Perkembangan } \\
\text { Pembelajaran Sejarah } \\
\text { Pasca } \\
\text { Kemerdekaan- } \\
\text { Reformasi (2019) }\end{array}$ & $\begin{array}{l}\text { History is a branch } \\
\text { of science that } \\
\text { systematically } \\
\text { examines the } \\
\text { development as a } \\
\text { whole }\end{array}$ \\
\hline $\begin{array}{l}\text { Anggi Yuniarti, } \\
\text { Toddy Aditya }\end{array}$ & Literature review & $\begin{array}{lr}\text { SERVICE QUALITY } \\
\text { TERHADAP } \\
\text { KEPUASAN } \\
\text { MASYARAKAT } \\
\text { MASS } \\
\text { RAPID } \\
\text { (MRT) } & \\
\text { JAKARTA } & \text { DKI } \\
\text { STASIUN } & \text { LEBAK } \\
\text { BULUS } & \\
\text { PADA } & \text { MASA } \\
\text { PANDEMIK } & \\
\text { COVID-19 (2020) }\end{array}$ & $\begin{array}{l}\text { MRT must provide } \\
\text { the best service to } \\
\text { MRT users }\end{array}$ \\
\hline Dwi Widiyanti & $\begin{array}{l}\text { analysis } \\
\text { qualitative } \\
\text { descriptive }\end{array}$ & $\begin{array}{l}\text { Pengembangan Park } \\
\text { and Ride untuk } \\
\text { Meningkatkan } \\
\text { Pelayanan Angkutan } \\
\text { LRT Kota Palembang } \\
\text { (2019) }\end{array}$ & $\begin{array}{l}\text { operation of the } \\
\text { Sumatra LRT and } \\
\text { its connection with } \\
\text { other } \\
\text { transportation in } \\
\text { Palembang }\end{array}$ \\
\hline $\begin{array}{l}\text { Velie Valentine } \\
\text { Mutiasari Kurnia } \\
\text { Devi } \\
\text { A. Yunastiawan } \\
\text { Eka Pramana }\end{array}$ & $\begin{array}{l}\text { Analysis } \\
\text { Techniques }\end{array}$ & $\begin{array}{l}\text { JANGKAUAN } \\
\text { LAYANAN TRANS } \\
\text { JOGJA } \\
\text { TERHADAP } \\
\text { SEBARAN } \\
\text { AKTIVITAS } \\
\text { DI KAWASAN } \\
\text { PERKOTAAN } \\
\text { YOGYAKARTA } \\
(2020)\end{array}$ & $\begin{array}{l}\text { The system used } \\
\text { by Trans Jogja is } \\
\text { the Bus Rapid } \\
\text { Transit } \\
\text { system }\end{array}$ \\
\hline $\begin{array}{l}\text { Karmila Zahrani } \\
\text { Al Hayati } \\
\text { Ridho Al-Hamdi }\end{array}$ & $\begin{array}{lr}\text { qualitatively } & \text { by } \\
\text { using } & \\
\text { case } & \text { study } \\
\text { approach. } & \end{array}$ & $\begin{array}{l}\text { TRANSPORTASI } \\
\text { PUBLIK DAN } \\
\text { MEDIA SOSIAL: } \\
\text { PERSEPSI NETIZEN } \\
\text { TERHADAP } \\
\text { PELAYANAN BUS } \\
\text { TRANS JOGJA } \\
2016-2018 \text { (2019) }\end{array}$ & $\begin{array}{lr}\text { PT } & \text { AMI } \\
\text { cooperation } & \text { with } \\
\text { the } & \text { DIY } \\
\text { government in the } \\
\text { development of } \\
\text { the Trans Jogja } \\
\text { route }\end{array}$ \\
\hline
\end{tabular}




\begin{tabular}{|c|c|c|c|}
\hline $\begin{array}{l}\text { Rizky Arif } \\
\text { Nugroho } \\
\text {,Eko Budi Santoso } \\
\text { Cahyono Susetyo }\end{array}$ & $\begin{array}{l}\text { qualitative analysis } \\
\text { in the form of } \\
\text { triangulation }\end{array}$ & $\begin{array}{l}\text { Konsep Manajemen } \\
\text { Trans Batik Solo } \\
\text { sebagai Pendukung } \\
\text { Sektor Pariwisata di } \\
\text { Kota Surakarta (2019) }\end{array}$ & $\begin{array}{l}\text { Batik Solo Trans } \\
\text { mode allows } \\
\text { people to move } \\
\text { from one place to } \\
\text { another }\end{array}$ \\
\hline $\begin{array}{l}\text { Amaliah } \\
\text { Widyastuti } \\
\text { Rachmat, } \\
\text { Andi Luhur } \\
\text { Prianto, Hamrun, } \\
\text { St. Nurmaeta } \\
\end{array}$ & $\begin{array}{l}\text { quali } \\
\text { appr }\end{array}$ & $\begin{array}{l}\text { Pengembangan } \\
\text { Transportasi Publik } \\
\text { Berbasis Smart } \\
\text { Mobility Di Kota } \\
\text { Makassar (2019) }\end{array}$ & $\begin{array}{l}\text { BRT still passes } \\
\text { through public } \\
\text { roads because it } \\
\text { doesn't have a } \\
\text { Busway line }\end{array}$ \\
\hline $\begin{array}{l}\text { Qadriathi Dg Bau } \\
\text { Reza Muhajir } \\
\text { Batara Surya }\end{array}$ & $\begin{array}{l}\text { analysis } \\
\text { descriptive } \\
\text { statistics }\end{array}$ & $\begin{array}{l}\text { KINERJA } \\
\text { PELAYANAN BUS } \\
\text { TRANS } \\
\text { MAMMINASATA } \\
\text { DI KORIDOR } 3 \\
\text { KAWASAN } \\
\text { MAMMINASATA } \\
(2019)\end{array}$ & $\begin{array}{l}\text { The problem of } \\
\text { transportation in } \\
\text { the Mamminasata } \\
\text { Area is not only on } \\
\text { external factors, } \\
\text { but problems can } \\
\text { also occur in the } \\
\text { internal }\end{array}$ \\
\hline $\begin{array}{l}\text { Rilo Haekal } \\
\text { Akhmad Yulizar } \\
\text { Alfa Narendra }\end{array}$ & dir & $\begin{array}{l}\text { ANALISIS } \\
\text { HUBUNGAN } \\
\text { JUMLAH } \\
\text { PENUMPANG DAN } \\
\text { WAKTU } \\
\text { PELAYANAN BRT } \\
\text { TRANS } \\
\text { SEMARANG DI } \\
\text { HALTE SIMPANG } \\
\text { LIMA DAN HALTE } \\
\text { KAMPUNG } \\
\text { PELANGI (2019) }\end{array}$ & $\begin{array}{l}\text { Development of } \\
\text { main corridor, } \\
\text { special corridor, } \\
\text { feeder corridor for } \\
\text { Trans Semarang } \\
\text { BRT in } 2020\end{array}$ \\
\hline $\begin{array}{lr}\text { Reditya } & \text { Filza } \\
\text { Priatama, } & \text { Ari } \\
\text { Subowo } & \end{array}$ & rese & $\begin{array}{l}l \\
\text { EVALUASI } \\
\text { PELAKSANAAN } \\
\text { KEBIJAKAN BUS } \\
\text { RAPID TRANSIT } \\
\text { (BRT) TRANS } \\
\text { SEMARANG RUTE } \\
\text { KORIDOR } \quad \text { VI } \\
\text { JURUSAN "UNDIP- } \\
\text { UNNES" (2020) } \\
\end{array}$ & $\begin{array}{l}\text { The } \\
\text { implementation of } \\
\text { the Trans } \\
\text { Semarang BRT } \\
\text { changes the } \\
\text { transportation } \\
\text { system to be more } \\
\begin{array}{l}\text { organized and } \\
\text { orderly }\end{array}\end{array}$ \\
\hline Hendra Wijayanto & $\begin{array}{l}\text { Implementation } \\
\text { method }\end{array}$ & $\begin{array}{l}\text { Peranan Penggunaan } \\
\text { Transportasi Publik di } \\
\text { Perkotaan } \\
\text { (Studi Kasus } \\
\text { Penggunaan Kereta } \\
\text { Commuterline } \\
\text { Indonesia } \\
\text { Rute Jakarta-Bekasi) } \\
(2019)\end{array}$ & $\begin{array}{l}\text { The state should } \\
\text { create public } \\
\text { transportation } \\
\text { facilities that make } \\
\text { it easier for its } \\
\text { people }\end{array}$ \\
\hline Anggela & analysis & POTENSI & It is necessary to \\
\hline
\end{tabular}




\begin{tabular}{|c|c|c|c|}
\hline Utami & $\begin{array}{l}\text { descriptive } \\
\text { statistics }\end{array}$ & $\begin{array}{l}\text { TRANSPORTASI } \\
\text { UMUM } \\
\text { DALAM } \\
\text { MENDUKUNG } \\
\text { PENGEMBANGAN } \\
\text { PARIWISATA } \\
\text { KOTA PALANGKA } \\
\text { RAYA (2020) } \\
\end{array}$ & $\begin{array}{lr}\text { improve integrated } \\
\text { public transport } \\
\text { services }\end{array}$ \\
\hline $\begin{array}{l}\text { Mohammad } \\
\text { Benny Alexandri } \\
\text { Nurillah Novel }\end{array}$ & $\begin{array}{l}\text { qualitative and } \\
\text { descriptive }\end{array}$ & \begin{tabular}{l}
\multicolumn{2}{l}{ PENGELOLAAN } \\
ANGKUTAN KOTA \\
DI $\quad$ INDONESIA \\
$(2019)$
\end{tabular} & $\begin{array}{l}\text { The DKI Jakarta } \\
\text { government } \\
\text { created the Jak } \\
\text { Lingko system for } \\
\text { the integration of } \\
\text { public } \\
\text { transportation in } \\
\text { Jakarta }\end{array}$ \\
\hline $\begin{array}{l}\text { Fitri Suryani } \\
\text { Ricky } \\
\text { Natadipura } \\
\text { Halimah Tunafiah }\end{array}$ & $\begin{array}{l}\text { survey research } \\
\text { methods }\end{array}$ & $\begin{array}{l}\text { OPTIMALISASI } \\
\text { RUTE } \\
\text { PERJALANAN } \\
\text { SARANA } \\
\text { ANGKUTAN } \\
\text { UMUM } \\
\text { TERPADU BOGOR - } \\
\text { JAKARTA (2019) } \\
\end{array}$ & $\begin{array}{l}\text { Transportation } \\
\text { costs describe } \\
\text { people's } \\
\text { expenditures in } \\
\text { paying } \\
\text { transportation } \\
\text { costs }\end{array}$ \\
\hline $\begin{array}{ll}\text { Mar } & \text { Atun } \\
\text { Nasikhah } & \end{array}$ & $\begin{array}{l}\text { descriptive } \\
\text { method. }\end{array}$ & $\begin{array}{l}\text { INOVASI } \\
\text { PELAYANAN } \\
\text { TRANSPORTASI } \\
\text { PUBLIK BERBASIS } \\
\text { TEKNOLOGI } \\
\text { INFORMASI (2019) } \\
\end{array}$ & $\begin{array}{l}\text { Information } \\
\text { technology-based } \\
\text { public services } \\
\text { need to be } \\
\text { implemented }\end{array}$ \\
\hline $\begin{array}{l}\text { Dini Nurdiani } \\
\text { Winny Astuti } \\
\text { Erma Fitria Rini }\end{array}$ & $\begin{array}{l}\text { quantitative } \\
\text { approach, }\end{array}$ & $\begin{array}{l}\text { KESESUAIAN } \\
\text { SISTEM } \\
\text { TRANSPORTASI } \\
\text { UMUM DI KOTA } \\
\text { SURAKARTA } \\
\text { TERHADAP } \\
\text { KONSEP } \\
\text { TRANSPORTATION } \\
\text { FOR LIVABLE } \\
\text { CITY (2019) }\end{array}$ & $\begin{array}{l}\text { Public transport } \\
\text { routes need to } \\
\text { reach densely } \\
\text { populated areas }\end{array}$ \\
\hline $\begin{array}{l}\text { Rezki Tri Ananda } \\
\text { Putri } \\
\text { Sri Mariya }\end{array}$ & $\begin{array}{l}\text { quantitative } \\
\text { descriptive, }\end{array}$ & $\begin{array}{l}\text { EFEKTIVITAS BUS } \\
\text { TRANS PADANG } \\
\text { SEBAGAI MODA } \\
\text { TRANSPORTASI } \\
\text { PUBLIK DI KOTA } \\
\text { PADANG }(2020)\end{array}$ & $\begin{array}{ll}\text { Accessibility } & \text { in } \\
\text { terms of ease } & \text { of } \\
\text { movement } & \text { of } \\
\text { passengers } & \end{array}$ \\
\hline
\end{tabular}

